\title{
The Use of Talisman in William Butler Yeats's Poetry: A Signifier of the Objet Petit a
}

\author{
Serkan ERTIN \\ Department of Western Languages and Literatures, Kocaeli University \\ 41380, Kocaeli, Turkey \\ Tel: 0090-262-3032884Ｅ-mail: serkan.ertin@kocaeli.edu.tr
}

Received: 02-10- 2012

doi:10.7575/ijalel.v.2n.1p.216
Accepted: 07-11- 2012

Published: 01-01- 2013

\begin{abstract}
Yeats's poetry is quite rich in the imagery of loss, yearning for the glorious and distant past, and a search for identity. The Tower is almost emblematic of the poet's disillusionment with the modern and of his nostalgic desire for the longforgotten past. This article intends to analyse the social, political and psychological reasons underlying the sense of loss pervading through the particular book and in order to keep reliability of the order of poems or their presence in the book, The Variorum Edition of Alspach and Allt, including the final texts, will be used, otherwise it would be rather difficult to follow the poems as Yeats is notorious for his revising his poems and even the order of the poems in his books.
\end{abstract}

Keywords: Yeats, talisman, romanticism, nationalism, nostalgia

\section{Introduction}

William Butler Yeats's poetic career is usually categorised into three rather distinct periods: The first one is his early period, in which, he is regarded as having been under the influence of Fin de Siècle movement in London. Eddins (1996) in his preface to Yeats: The Nineteenth Century Matrix takes it further and claims that he was "under the influence of the Elizabethans and Romantics" because he was educated by his father who taught him Shakespeare and Shelley particularly (p.viii). Thematically, in this period, he saved from facile sentimentalism only by his tone of impersonality. Otherwise it would be difficult to distinguish The Sorrow of Love, in which Yeats contrasts the world of man and nature in the context of his unreturned love, from any other Romantic or Pre-Raphaelite poem. The 1890s are considered a transitional era in his poetry, when he produced mystical poems. However, the common opinion, as Webster (1973) states in her introduction, was that he was neither satisfactory nor he himself was satisfied with his style and representations (p.1). Because he had not yet reached his maturity in terms of both form and content, he either paid too much attention to form itself, caring for rhyme patterns for instance, or he could not achieve impersonality and produced highly personal even autobiographical works.

\section{Theoretical Framework}

The Tower, published in 1928, marks the beginning of his third period. This book includes The Gift of Harun Al-Rashid but not Fragments, which was added in the Collected Poems in 1933. In the same year Yeats also changed the order of the poems in the book and substituted The Fool by the Roadside for The Hero, The Girl and The Fool (Allt, 1961, p.371). He was a very reader-conscious poet, and thus, in every single thing he did he had a reason. Therefore, before starting the discussion, I would like to mention the first impressions forming upon seeing the order of the names of the poems in The Tower, for the names and even the order of the poems have a significance in the book; Yeats must have had a reason to reorganise the poems and to give the poems these names:

Sailing To Byzantium, The Tower, Meditations In Time Of Civil War, Nineteen Hundred And Nineteen, The Wheel, Youth And Age, The New Faces, A Prayer For My Son, Two Songs From A Play, Fragments, Wisdom, Leda And The Swan, On A Picture Of A Black Centaur By Edmund Dulac, Among School Children, Colonus' Praise, The Hero, The Girl, and The Fool, Owen Aherne And His Dancers, A Man Young And Old, The Three Monuments, The Gift of Harun Al-Rashid, All Souls' Night.

As seen above there are twenty-one main poems in the book, which gives a total number of thirty-nine when subtitles are included. Starting with the first poem the reader sails for the ancient city Constantinople and after arriving at an ancient Tower he is expected to stop there and contemplate on the Irish Civil War, starting from a general topic to a more specific one. The year is Nineteen Hundred And Nineteen when the reader falls off The Wheel of fortune and goes back to past for a while. There comes the comparison of the past to the present, which will indeed be one of the major themes of the book. The intended reader encounters the present in The New Faces, which are The Fragments taken out of life indeed, memories kept in Wisdom. Then once more the reader gets on time's winged chariot to go back to past to 
visit some mythological figures. While watching the beauty of the swan tricked by Zeus, the reader suddenly wakes up to find himself Among School Children, in real life. This reminds one of the present world they live in. Yeats does not want his reader to get lost in the literal and deceptive meanings of myths. Then once more the reader travels to Colonus and overhears a conversation among The Hero, The Girl and The Fool, waking him up. Shortly after that, it is time for the reader to turn back-to-the-future to find himself before Owen Aherne and His Dancers. Comparison of the past to present is still being carried on within the context of A Man Young and Old. After visiting The Three Monuments and receiving The Gift of Harun Al-Rashid, the reader comes back to present and has a mystical vision, for it is All Souls' Night now.

\section{Analysis}

Yeats's organisation of the poems is in accordance with Bergson's concept of time in that one can never live only the present but the past, the present and the future at the same time. In this book Yeats wants to emphasise the fact of simultaneity by bringing the reader back-and-forth constantly. He distances his narration and sets it in past in mythology, yet his implications always refer to the present. This might be because of his allusive style. He does not write anything directly but attributes each thing a symbolic vague context. But why does he do that? Why does he need all this stuff? Why does he make use of mysticism, mythology or the supernatural so much? Is it a part of his defense mechanism, such as repression or escape? What devices does he use to achieve this objective? Webster (1973) in her introduction to the psychoanalytical study of Yeats's poetry ascribes the use of the occult to his "reawakened" fears of castration and the loss of integrity (p.3). These fears were already seen in his earlier poetry in the form of an escape. However, in this period his fears might be resulting from his old age and the approaching death. Webster seems to be right when he attributes Yeats's obsession with the past to his own fear of castration and loss of integrity. The poet lives the present but he cannot avoid the dependence upon the past. He constantly takes refuge in past, in the talismanic objects of past, against his fear of death.

The occult is one of the most important elements in his poetry. Obviously John O'Leary, the old Fenian leader, was the one influencing him. Magic was the business of his life, as Yeats states: "If I hadn't made magic my constant study I couldn't have written a single word of my Blake book, nor would The Countess Cathleen have ever come to exist. The mystical life is the centre of all that I do and all that I think and all that I write" (Ctd. in Unterecker, 1988, p.11). At this point it is even clearer that Yeats would not have come to terms with his inner conflicts or problems such as aging if it had not been for the talismanic objects in which he found an emotional refuge. Sure the use of talismanic objects and mysticism do not only raise psychological questions about Yeats but also point at another layer of meaning, i.e. the mind of a poet under colonial oppression, since "Yeats's willful mysticism and incoherence do embody a revolutionary potential in the poet's insistence that Ireland should retain its culture by keeping awake its consciousness of metaphysical questions" (Said, 1990, p.81). In his poetry we can always find statements or implications of his dissatisfaction with the modern society and institutions, which takes the reader to one of the major themes in The Tower, and there comes the time to sail to Byzantium to see it in detail.

The myth of Byzantium Empire, where life is entirely reflected onto art, is one of the common talismans in the book. Yeats explains the significance of this city in "A Vision" and admits if he were given a month in antiquity and was given a chance to spend it whereever he chose, he would spend it in Byzantium, a little before Justinian opened St.Sophia and closed the Academy of Plato (Ctd. In Allt, 1961, p. 172). Yeats believed that all religious, aesthetic and practical lives were one in Byzantium, all artists were impersonal and they had the vision of wholeness reflected in a single image. This is indeed a reflection of one of the modern characteristics of his poetry because as a modern poet he always aimed at organic unity and he did not try to compose single poems, but instead he wove works of art as if he were dealing with a set of lace. For example, "A Man Young and Old" is accepted as the first part of a poem, "A Woman Young and Old". Likewise, the book, The Tower itself as a whole, is the first part of a pair completed by "The Winding Stair".

"Sailing to Byzantium" is the first poem of the book dealing with the myth of Byzantium. Before analysing the reasons why Yeats longed for Byzantium so deeply, a brief look at his conception of the modern world may give us an insight into his poetry: "A walking mummy, flames at the street corners where the soul is purified. Birds of hammered gold singing in the golden trees. In the harbor dolphins offering their backs to the wailing dead that they may carry them to paradise" (Ctd. in Allt, 1961, p.825). This notion could be related to Yeats's so-called fascist tendency as he is said to have despised democracy, modern world, science, machinery and even human equality but favoured the feudal structure instead. The ideal civilisation for Yeats was a "hierarchical, every great man's door crowded at dawn by petitions, great wealth everywhere in a few men's hands, all dependent upon a few, upto the emperor himself who is a god dependent on a greater god, and everywhere, in Court, in the family, an inequality made law" (Orwell, 1975, p.351). However, these lines might as well be regarded as exaggerated modern sentimentalism if one takes his description of his ideal civilisation ironic. Those considering Yeats fascist may be failing to grasp his actual thought, for the may be a very deep scar lying behind his harsh words. He could simply be longing for an empire like Byzantium as he strongly disliked that of Britain. As an Irish poet using English he must have suffered a lot for Irish literary survival, and therefore, the influence of his own background is inevitable in the imagery he uses in his poetry.

Until 1922 Ireland as a whole was occupied and ruled by Britain. The occupation had begun hundreds of years before but only from the end of the eighteenth century a stronger Irish nationalism came out. Said (1990) distinguishes European imperialism from all others because of some reasons: "First the extraordinary and sustained longevity of the disparity in power between Europe and its possessions, and second, the massively organized rule, which affected the 
detail and not just the large outlines of life, of that power" (p.71). The usual pretext for colonialism is of course the intention to modernise, develop, instruct and civilise the native people of a country. Thus, there was always the distinction between the binaries the British and the Others. However, as seen in Said's statements, British Empire caused radical changes in her colonies. In other words, the British imperialism changed every single place it touched to a great extent and the consequence for some people turned out to be excessive sentimentalism.

Nationalism is a resistance to imperialism by the people with a common history, religion and language. This is what happened in Ireland; people resisted the imperial powers but the problem was that, according to Said, these struggles were led by bourgeoisies. When they replaced the colonial forces in Ireland what they did was to re-impose "the old colonial structures replicated in new national terms" (Said, 1990, p.74). This was perhaps the second disillusionment for Yeats within the nationalist struggles as they not only fought the imperialists but also the bourgeoisie. He was totally disappointed with the result of the movements and he expresses his feelings in September 1913: "Romantic Ireland's dead and gone / It's with O'Leary in the grave" (Ctd. in Abrams, 1993, p.1873). When the reader goes back to "Sailing to Byzantium" in the light of the colonial context, the first thing to notice will be the binary opposition, which will be carried on throughout the book, between the old and the young. The native country described here is not proper for the old man, as he sees himself as "a tattered coat upon a stick" (Ctd. in Abrams, 1993, p.1883). However, the words "unageing intellect" and "sensual" are foreshadowing as they sharply differ with the ageing body of the man. Nevertheless, the contrast still exists between body and mind in relation to the one between the young and the old. The "sensual music" refers to the teachings of the imperialists and it is negligent according to Yeats. He even got "sick with desire" in the end and this is why he has come "to the holy city of Byzantium" (Allt, 1961, p.408). He wants to get out of Irish nature which torments his soul and identifies himself with the golden bird made by Grecian goldsmiths, as he states in his famous couplet:

\section{Once out of nature I shall never take / My bodily form from any natural thing}

But such a form as Grecian goldsmiths make / Of hammered gold and gold enamelling. (Allt, 1961, p.408)

The couplet gives a very good example of a talismanic object in Yeats's work, i.e., the lasting objects he uses to overcome his tensions, fears or dis-eases. Now that he associates himself with art he is not a human being suffering in the modern world, but a beautiful object of art in ancient times, which is obviously a function of his defense mechanism, i.e., an escape.

Another poem depicting almost the same image is "Meditations in Time of Civil War". This poem has seven sub-titles following a deductive order, starting with "Ancestral Houses" and then continuing with "My House" and then "My Table" and so on. Now another binary is added to the young / the old and the present / the past binaries, which is the one between nature and culture. Yeats begins the poem with a beautiful depiction of the nature and country life. However, between the lines 16-24 there is a straightforward criticism of the bourgeoisie, the colonial, "the inherited glory of the rich"(Ctd. in Allt, 1961, p.418). Yeats argues that there is no gentleness indeed and the great-grandson of the ancestral house is but a mouse. The fourth and the fifth stanzas, line 31 to be specific, deal with the comparison of the past to present in the context of the delight of childhood. Then, in line 40, the "greatness" of the ancestors is compared to "bitterness" and to the violence of the present (Ctd. in Allt, 1961, p.418). In the second part of the poem the focus is on a farmhouse "sheltered" by the wall of the tower. Now the talismanic power is embodied in the tower itself and Yeats takes shelter under the wings of the tower, on both a literal and a metaphorical level as this tower was a real one in his own garden, where he might have had meditations in time of civil war. This is again a form of escape used when one cannot cope with the harsh realities in life. In the next two parts the tone is the same but only the talisman differs, shifting from a table, "unchanging like the sword", to the "stones" of the house as only they could stand against the destructive power of time and culture (Ctd. in Allt, 1961, p.423). In the fifth part of the poem when some officers come and stand before his door he complains "of the foul weather, hail and rain", which is once more an escape from the severe facts of war time to the affectionate arms of nature. Next part does the same thing by giving the sharp contrasts between man and nature. Here the 'bard' calls at the honey-bees and in this conversational style he mentions the civil war and the young people dying at war. He ascribes it to our having "more substance in our enmities / Than in our love" (Ctd. in Allt, 1961, p.423).

Similar to "September 1913", "Nineteen Hundred Nineteen" takes the same theme, the obsession with the past in a clearer and a more sarcastic manner. It sets the main idea in the very first line: "Many ingenious lovely things are gone" (Ctd. in Allt, 1961, p.428). In the second stanza we once more encounter the romantic or neo-platonic theme of childhood. He again, like Blake, praises the innocence possessed only in childhood: "We too had many pretty toys when young / A law indifferent to blame or praise" (Ctd. in Allt, 1961, p.428). Sure in this respect he was influenced by William Blake, and therefore, we can find in Yeats's poetry the idealisation of childhood and the bitterness of experience. The purity people have when they are children is resembled to "toys" here. In the twelfth line there is an allusion to the myth of Icarus. Icarus is the son of Daedalus, who flew with the wax wings but fell down as he approached the sun too much. This downfall of Icarus is used in the poem to refer to the loss of innocence, as we are the descendents of him for we made a very big mistake by believing that "rascals had died out" (Ctd. in Allt, 1961, p.428). In the fourth stanza the comparison turns to today and the reader finds himself among quite gloomy words, describing the difficult conditions of Irish people those years: 
Now days are dragon-ridden, the nightmare / Rides upon sleep: a drunken soldiery

Can leave the mother, murdered at her door / To crawl in her own blood, and go scot-free (Ctd. in Allt, 1961, p.429)

So the presence of anarchy is felt throughout the stanza. The fifth part of the poem is the most sarcastic part in fact: "Come let us mock at the good / That fancied goodness might be gay" (Ctd. in Alt, 1961, p.429). Here mockery is mocked by Yeats, and the people of course, especially the treasoners who supported imperialism. This poem adds to the theme of sweet past versus bitter present but with a more direct and arrogant tone.

A very short look back is given in "Youth and Age", a very succinct depiction of Yeats's attitude towards colonial oppression in past and in present. When he was younger, he says: "Much did I rage" but in time this passionate nationalism came to an end as he saw the Romantic Ireland he looked for or tried to revive was in fact far away. "His early and invented Ireland was amenable to his imagination whereas he ended by finding an Ireland recalcitrant to it" (Said, 1990, p.80). Thus, he was quite different later on, especially after he started to accept things as they were, "with flattering tongue" (Ctd. in Allt, 1961, p.434). The influence of this recognition was also seen in his poetry as he did not take refuge of talismanic objects in his later poetry.

"Leda and the Swan" is a real masterpiece in the book as it holds multiple layers of meaning. On the first level when one -if educated- reads it he cannot help finding himself in the famous myth of Zeus and Leda. In the particular myth Zeus tricked and seduced Leda in the disguise of a swan. Leda, in Hamilton version, is described as the wife of King Tyndareus of Sparta and the known story is that she bore two mortal children to him, Castor and Clytemnestra; and to Zeus two immortal ones, Helen and Pollux. In the poem she is depicted as a very elegant but unlucky girl as she was raped by Zeus. The choice of the words in the poem indeed tells us the true story;

A sudden blow: the great wings beating still

Above the staggering girl, her thighs caressed

By the dark webs, her nape caught in his bill,

He holds her helpless breast upon his breast. (Ctd. in Allt, 1961, p.441)

Apparently the poor girl yields to the huge swan. This is what one gets at first sight but the last two stanzas present another level of reality and another layer of meaning: the Trojan War. The tenth line starts with the depiction of "burning roof and tower", a depiction of Troy after the war. The Trojan War in short was fought because of Helen, the most beautiful mortal woman, who escaped with Paris to Troy and caused the downfall of the city, for the Greek army destroyed the antique city altogether after a war of nine years. Thus, this is a criticism of the Greeks as they burnt up everything there, even the tower which proves to be a very important phallic symbol for Yeats. Another interpretation of the poem is of course the anti-colonist one, identifying Zeus and the Greeks with the English and Leda and the Trojans with the Irish.

Belonging to a nation which suffered from the imperialist policies of Britain, Yeats could not ever get rid of the influence of this oppression and he -deliberately or not- reflected the issues related to colonisation in his poetry. Explaining this poem he comments:

I imagine the annunciation that founded Greece as made to Leda, remembering that they showed in a Spartan temple, strung up to the roof as a holy relic, an unhatched egg of hers; and that from one of her eggs came Love and from the other War. But all things are from antithesis, and when in my ignorance try to imagine what older civilization that annunciation rejected I can but see bird and woman blotting out some corner of the Baylonian mathematical starlight. (Yeats, 1983, 188)

The annunciation mentioned refers to the rape theme, that of Leda by Zeus disguised as a swan, causing the birth of Helen but the collapse of the legendary city of Troy. However, the analysis of the poem implies the shifting passions of Leda and Zeus. At the beginning of the poem Zeus had been "passionate" and Leda "helpless and terrified" (remember the word "caught") but in the end Leda is "caught up" in his passion and Zeus "indifferent" (Ctd. in McKenna, 1983, p.188). This reminds me of the structure of hegemony, in Gramsci's term. Because hegemony survives through the consent of people as the ruling class convinces the others that its interests are the interests of all. It is a very subtle way of dominating people. Therefore, an accusation of Leda, namely of the Irish, can be found out according to this interpretation. Said (1990) also mentions the colonial eyes of Yeats in this poem and that Yeats wants "to reconcile the inevitable violence of the colonial conflict with the everyday politics of an ongoing national struggle" (p.90).

"Among School Children", another famous poem of the book, when attention is paid to its stanza forms -eight, to number, each consisting of eight lines- and its rhyme patterns, is obviously an outcome of a very close study and observation. Children, as a theme, have platonic connotations and romantic elements as well, for childhood is accepted as the golden age of human life that can never come back once lost. Children at present are both our past and future. This is why Yeats uses them as a theme to join people to their history to form their future as well. As a poet of a colonized country he was very sensitive about nationality and therefore he tried to revive Irish culture and literature by linking past to future. For him "history and the nation were not separable, any more than a dancer was separable from the dance" (Said, 1990, p.92).

Similarly, McKenna defines this poem as "an effort to synthesize the sixty-year-old smiling public man, the aged onetime lover, and would be philosopher into something as organic as a chest-nut tree, as coherent as a dancer's 
movements" (p.191). McKenna also refers to some trios in the poem, such as three images worshipped; lovers, nuns and mothers, but the basic trio underlying the poem - as I have aforementioned- is among past-present and future, among childhood-maturity and old age in other words. And Yeats is the poet combining all these aspects in his poetry as he is a real poet having the association of sensibility. He never aims at presenting his readers a single experience or a single image but he amalgamates all his ideas and produces organic works of art. Even this poem parallels Colonus' Praise in terms of the dancing or the tree images existing in both poems (McKenna, 1983, p.193). Owen Aherne and His Dancer, even, is an extension of the same theme of dancing.

In the first stanza of the poem the present is compared to past by the contrast between the old nun and the "sixty-yearold public man" (Ctd. in Allt, 1961, p.443). Webster comments on this second "tattered protagonist", the first one was in "Sailing to Byzantium", and states that in this poem more things are lost than are retained (p.219). In the next stanza he goes back to the myth of Leda and remembers the sorrowful story of Ireland:

"I dream of a Ledaean body, bent / Above a sinking fire, a tale that she

Told of a harsh reproof, or trivial event / That changed some childish day to tragedy" (Ctd. in Allt, 1961, p.443).

The third stanza extends the criticism and refers to Helen, as she was one of the "daughters of swan", who caused the fall of Troy (line 20). However, he does not want to contemplate on past anymore as he does not want to scare the children. Here another use of talisman appears in the form of "an old scarecrow" which provides a sense of relief and comfort for him:

"Better to smile on all that smile, and show

There is a comfortable kind of old scarecrow" (Ctd. in Allt, 1961, p.446).

The same object is repeated in line 48, too, as "old clothes upon old sticks to scare a bird" (Ctd. in Allt, 1961, p.446). He probably associates himself with the old scarecrow and takes over the mission of scaring the birds, that is struggling for the revival of Irish culture against British hegemony. The chest-nut tree in the eighth stanza must be another object for Yeats to "be gathered into the artifice of eternity" (Said, 1990, p.93). Reminding the reader of the Irish culture Yeats tries to revive, the chest-nut tree is depicted as "great-rooted blossomer" as if it symbolises their native traditions blossoming deep in soil, for it was oppressed by the British. Finally, Yeats states the impossibility of separating "the dancer" from "the dance", which might be taken as the unity of country and nation or the poet and native culture. Said, for instance, takes this metaphor as the representations of history and nation (p.92).

Most of the other poems in The Tower deal with different pages of life, such as love or death. However they do not involve as strong talismanic objects as the ones mentioned above for Yeats seems to have developed his ego. He seems much more mature in these poems and in the following book as he does not need any object as a refuge anymore.

\section{Conclusion}

Yeats, the disillusioned nationalist bard, upset with the fall of Troy, tries to reconstruct the glorious city through his verse; as a poet he is as careful as a mason. Both the tower and the city he is trying to reconstruct seem to be symbolising the lost Irish culture and traditions, which the poet relentlessly attempts to revive. His struggle and the harsh conditions he experienced directly influenced his poems in The Tower and the imagery he employs in the book reveals how deeply he yearns for the lost identity and dignity. Perhaps the most important thing to defeat an enemy is the range of sight and the power of vision, and this could be the reason why the Trojans lost the war, which culminated in the destruction of their city. Yet Yeats the volunteer watchman of his own city is determined not to lose the war and his biggest arm for his eternal war is his power of vision.

\section{References}

Abrams, M.H. (Ed.). (1993). The Norton Anthology of English Literature. London: Norton\&Company.

Allt, P. and R. K. Alspach. (Ed.). (1961). The Variorum Edition of the Poems of William Butler Yeats. London: MacMillan.

Eddins, D. (1996). Yeats: The Nineteenth Century Matrix. Alabama: Alabama UP.

Hamilton, E. (1982). Mythology: Timeless Tales of Gods and Heroes. New York: Penguin.

McKenna, S. and M. Mac Liammor. (Ed). (1983). The Poems of W. B. Yeats. New York: New Rochelle.

Orwell, G. (1975) W.B.Yeats. In G.Martin and P.N. Furbank (Ed.), Twentieth Century Poetry: Critical Essays and Documents. Milton Keynes: The Open University P.

Said, E. (1990). Yeats and Decolonization. In T. Eagleton et al. (Ed.), Nationalism Colonialism and Literature. Minneapolis: Minnesota UP.

Unterecker, J. (1988). A Reader's Guide to W.B.Yeats. Yugoslavia:Thames and Hudson.

Webster, B. S. (1973). Yeats: A Psychoanalytic Study. California: Standford UP. 